\title{
Administração intralesional de iodeto de potássio a $15 \%$ no tratamento da pitiose: relato de caso
}

Juliana de Moura Alonso", Thiago Yukio Nitta, Sandra de Moraes Gimenes Bosco, Marcos Jun Watanabe, Ana liz Garcia Alves, Celso Antônio Rodrigues, Carlos Alberto Hussni

*Autor correspondente

e-mail: jumandril@hotmail.com

\section{Resumo}

A pitiose é uma doença granulomatosa do tecido cutâneo e subcutâneo causada pelo oomiceto Pythium insidiosum. A presença de pitiose na região distal dos membros associada a um longo período de evolução apresenta um mau prognóstico. Relata-se o caso de um equino, fêmea, dois anos de idade, da raça Mangalarga Paulista, oriunda de propriedade com área de açude, apresentando ferida granulomatosa na região medial de metatarso esquerdo em seu terço distal associada à presença de prurido e sinais de automutilação. Ao atendimento foi relatado o aparecimento da ferida há três meses e descrita ausência de cicatrização e piora clínica após tratamento inespecífico realizado. Macroscopicamente, observou-se a presença de ferida granulomatosa de aproximadamente $5 \times 5 \mathrm{~cm}$ com trajetos fistulosos profundos, apresentando secreção serosanguinolenta e a presença de concreções amareladas (Kunkers) entremeadas à granulação. Apesar do aspecto clássico da ferida associado ao prurido intenso sugerir o diagnóstico de pitiose, realizou-se a confirmação laboratorial microbiológica, onde foi observada a presença de hifas com identificação do agente. Devido à localização da lesão e ao tempo de evolução apresentado, optou-se pela instituição de terapia associada, consistindo na exérese da granulação seguida de termocauterização, administração diária oral de iodeto de potássio (67mg/Kg 60 dias) e infiltração com $60 \mathrm{~mL}$ de solução saturada de iodeto de potássio em água destilada a 15\% na lesão, em aplicação única 48 horas após excisão cirúrgica. Considerado o mau prognóstico em casos de pitiose localizados abaixo de carpo e de tarso, optou-se pela associação terapêutica com a infiltração local com iodeto de potássio, sendo que este procedimento nunca fora anteriormente descrito. A administração intralesional de iodeto resultou em necrose tecidual e aumento da lesão nas primeiras 72 horas após administração, entretanto, após este período observou-se progressiva cicatrização da ferida com epitelização total após 82 dias. Este caso sugere que o tratamento associado com a administração intralesional de iodeto de potássio tenha contribuído para a remissão da infecção, 
devendo-se evoluir nos estudos com este método terapêutico na busca da eficiência nos tratamentos da pitiose.

Palavras-chave: Cavalos. Ferida. Granulação. 